\title{
Prevalence of Human Cytomegalovirus in Breast Cancer: A Systematic Review
}

\author{
Mohsen Nakhaie ${ }^{1.2}$, Javad Charostad ${ }^{1.3}$, Hossein Ghaderi-Zefrehi ${ }^{4}$, Seyyed Ali \\ Mohammad Arabzadeh ${ }^{2}$, Fatemeh Pourhosseini ${ }^{5}$, Manoochehr Makvandi $^{1}$
}

${ }^{1}$ Department of Medical Virology School of Medicine, Ahvaz Jundishapur University of Medical Sciences, Ahvaz, Iran. ${ }^{2}$ Department of Medical Microbiology, Kerman University of Medical Sciences, Kerman, Iran. ${ }^{3}$ Department of Microbiology, Shahid Sadoghi University of Medical Science, Yazd, Iran. ${ }^{4}$ Department of Clinical Biochemistry, Faculty of Medicine, Ahvaz Jundishapur University of Medical Sciences, Ahvaz, Iran. ${ }^{5}$ Department of Pathology, School of Medicine, Shahid Sadoughi University of Medical Sciences, Yazd, Iran.

\begin{abstract}
Background: Breast cancer is the most common malignancy among women around the world, with several risk factors contributing to its progression. The role of infectious agents such as viruses in the progression of this cancer is relatively well-known, as a result of various studies in different geographical regions that reported the prevalence of cytomegalovirus in breast cancer. Objective: In this systematic review, we tried to examine the prevalence of cytomegalovirus in breast cancer. Materials and Methods: We conducted a comprehensive search of three databases: PubMed, Scopus, and Google Scolar up to January 21, 2021. Results: Out of 584 articles, 29 articles including 3158 samples were finally reviewed, of which 16 articles used PCR methods, 8 articles used serology method and 13 articles used other methods such as immunohistochemistry and in situ hybridization. The prevalence of the virus was higher in Asian and African countries such as Iraq and Egypt than other European and South American countries. Among these, the highest prevalence of the virus in different samples of patients with breast cancer was related to Iraq. Conclusion: The results of our study showed the higher prevalence of the virus in patients with breast cancer rather than normal subjects and reveal the role of the virus in the development of breast cancer.
\end{abstract}

Keywords: Breast Neoplasms- Cytomegalovirus- Prevalence- Systematic review

\section{Introduction}

Malignancies are one of the leading causes of death in this century. According to evidence, 9.6 million people died of cancer only in 2018 worldwide that among them breast cancer with 626679 cases of death has been introduced as the most common cancer among women around the world [1]. However, this type of malignancy has a worldwide prevalence, its incidence, mortality, and survival rate vary significantly in different parts of the world [2]. An important point in increasing the incidence of breast cancer in communities may originate from risk factors variations [3]. Breast cancer can be associated with various factors such as demographic structures, lifestyle, genetic factors, environment and etc [2]. The incidence of breast cancer can be strongly related to race and ethnicity [4]. The incidence of this malignancy in different parts of the world varies from 27 per 100,000 people (Central Africa and East Asia) to 92 per 100,000 people (North America) [5]. Extensive researches from around the world have clarified that there is an almost 4-fold difference in the incidence of breast cancer between developed and undeveloped countries, which reveals the profound impact of environmental factors on the process of disease development [1]. As mentioned, there are several factors involved in the development of breast cancer malignancy, which according to the International Agency for Research on Cancer the biological carcinogens are

Corresponding Author:

Dr. Manoochehr Makvandi

Department of Medical Virology School of Medicine, Ahvaz Jundishapur University of Medical Sciences, Ahvaz, Iran.

Email: manoochehrmakvandi299@gmail.com 
one of the influential factors in this process [6]. Biological carcinogens are one of the most important factors involved in breast cancer promotion. Over the past decades, the hypothesis of the role of viruses in breast carcinogenesis has attracted extensive attention. The viruses including human papilloma viruses (HPVs), Epstein-Barr virus (EBV-also known as human herpes virus type 4), mouse mammary tumor virus (MMTV), bovine leukemia virus (BLV), and human cytomegalovirus (HCMV) have been mentioned to be related to breast cancer [7]. Although the exact role of these viruses in the breast cancer remains controversial, large body of studies reported an association between HCMV and breast cancer [8].

The HCMV is a member of the herpesviridae family that has the ability to cause latent infections among individuals [9]. This virus, like most members of the herpesviridae family, is highly prevalent in different communities, with prevalence rate of 50 to $100 \%$ around the world [9]. The features including targeting cancer-related factors $\mathrm{Rb}$ and $\mathrm{p} 53$, the ability of cellular transformation "in vitro", encoding proteins with oncogenic functions such as IE and pp65, employing mechanisms of oncomodulation and evading the immune system responses, have turned HCMV into an influential factor involved in pathogenesis of human malignancies, such as glioma, neuroblastoma, and breast cancer [10-11]. Existing data has shown the presence of CMV in different samples of patients with breast cancer [8]. In this study, we tried to assess the prevalence of CMV in patients with breast cancer. We also aimed to highlight the prevalence rate of CMV in tissue and also its serum of patients' prevalence in different regions of the world by comparing different methods.

\section{Materials and Methods}

\section{Literature search strategy}

This systematic review investigated the techniques including conventional Polymerase chain reaction (PCR), Nested-PCR, Real-time PCR, serological, immunohistochemistry, and hybridization for determining the prevalence of HCMV in patients with breast cancer. The PubMed, Scopus and Google Scholar databases were searched up to January 21, 2021 using combinations of the following key words: (Cytomegalovirus OR Cytomegalovirus infection OR CMV OR human herpesvirus-5 OR HCMV) and (breast cancer OR breast neoplasm OR breast tumor OR cancer of breast OR human mammary neoplasm OR human mammary carcinoma OR breast carcinoma).

\section{Study selection}

At first, the selected articles were entered into EndNote software version X8 from three databases and the duplicate items were removed, then by screening the titles and abstracts, a number of articles were also deleted. The remaining studies were reviewed by two reviewers based on established criteria.

\section{Inclusion and exclusion criteria}

Studies with pre-determined criteria were selected for the current study which include: a) All case-control and cross-sectional studies conducted based on the conventional PCR, Nested-PCR, Real-time PCR, serological, immunohistochemistry, and hybridization methods for determining the prevalence of HCMV in patients with different types of breast cancer, b) Studies examining fresh tissue or formalin-fixed paraffin embedded (FFPE) tissues, blood, plasma, serum c) Utilization of samples of adjacent normal tissue or healthy individuals without breast cancer, fibroadenoma and benign as a control group, d) Full text studies in English.

Exclusion criteria also include: a) Review studies, case reports, abstract, master's thesis or doctoral thesis and letter to editor, b) Studies on cell culture and animal, c) Studies that have used benign tissues such as fibroadenoma, fibrocystic, mastitis as a case sample, d) Studies that have considered non-inflammatory breast cancer samples as controls, e) Samples of cancer or normal are related to men, f) Studies that have used diagnostic methods conventional PCR, Nested-PCR, Real-time PCR, serological, immunohistochemistry, and hybridization, g) Studies that have examined the effect of the drug on HCMV-related breast cancer, h) Studies published in languages other than English.

\section{Data Extraction}

For each included study, two authors reviewed and extracted following data: author name, year of study, country of study, type of study, sample size, type of cancer, type of specimen, type of method used and results of the study are reported numerically and as a percentage.

\section{Ethical Review and Reporting}

Given that this systematic review study used the results of others studies and did not use directly human samples or animal, therefore was not submitted for any ethical approval. This study is reported according to the Preferred Reporting Items for Systematic Reviews and Meta-Analyses (PRISMA) statement.

\section{Results}

\section{Literature Search}

The article selection flowchart is shown in Figure 1. Initially, 584 articles were selected from three databases by searching for the relevant keywords, and after removing the duplicate items, 341 articles remained. 288 articles were excluded due to irrelevance to the subject by reviewing the titles and abstracts of the articles by three reviewers. 24 articles removed due to unclear data and non-relevant records. The remaining 29 articles were reviewed in full text, of which 16 articles used PCR methods, 8 articles used serological method, 9 articles used immunohistochemistry (IHC) method, 4 articles used in situ hybridization (ISH) techniques and 7 articles employed the mentioned techniques in combination. In addition, Tables 1 to 3 provides information such as techniques used, type of tissue studied, target gene studied, 
Table 1. Comparison of CMV Positivity between Breast Tumor Tissue and any Controls by PCR Methods

\begin{tabular}{|c|c|c|c|c|c|c|c|c|c|c|}
\hline \multirow[t]{2}{*}{ Gene } & \multirow{2}{*}{$\begin{array}{l}\text { Type of } \\
\text { Tissue }\end{array}$} & \multirow[t]{2}{*}{ Test } & \multirow[t]{2}{*}{ Studies } & \multicolumn{3}{|c|}{ Cases } & \multicolumn{3}{|c|}{ Controls } & \multirow{2}{*}{$\begin{array}{l}\text { Significant } \\
\text { Correlation }\end{array}$} \\
\hline & & & & $\begin{array}{c}\text { No. } \\
\text { Positive }\end{array}$ & $\begin{array}{c}\text { No. } \\
\text { Tested }\end{array}$ & Positivity & $\begin{array}{c}\text { No. } \\
\text { Positive }\end{array}$ & $\begin{array}{c}\text { No. } \\
\text { Tested }\end{array}$ & Positivity & \\
\hline IE & FFPE & PCR & $\begin{array}{l}\text { Aidrous et al, } \\
\text { 2019, Sudan. [12] }\end{array}$ & 0 & 42 & 0 & 0 & 18 & 0 & No \\
\hline \multirow[t]{4}{*}{ gB } & FFPE & PCR & $\begin{array}{l}\text { Sepahvand et al, } \\
\text { 2019, Iran. [13] }\end{array}$ & 20 & 37 & 54.04 & 10 & 35 & 28.5 & Yes \\
\hline & Fresh & Real-time PCR & $\begin{array}{l}\text { El Shazly et al, } \\
\text { 2018, Egypt. [14] }\end{array}$ & 11 & 61 & 18 & 0 & 61 & 0 & Yes \\
\hline & FFPE & & & & & & & & & \\
\hline & FFPE & Real-time PCR & $\begin{array}{l}\text { Shadood et al, } \\
\text { 2018, Iraq [15] }\end{array}$ & 5 & 80 & 6.25 & 1 & 20 & 5 & No \\
\hline \multirow[t]{2}{*}{$\mathrm{gB}$} & FFPE & PCR & $\begin{array}{l}\text { Bakhtiyrizade et al, } \\
\text { 2017, Iran [16] }\end{array}$ & 0 & 150 & 0 & 2 & 150 & 1.3 & No \\
\hline & & Real-time PCR & & & & & & & & \\
\hline IE & FFPE & Real-time PCR & $\begin{array}{l}\text { Mohammadizadeh et al, } \\
\text { 2017, Iran [17] }\end{array}$ & 0 & 70 & 0 & 0 & 26 & 0 & No \\
\hline gB & $\begin{array}{l}\text { formlin- } \\
\text { fixed }\end{array}$ & Nested PCR & $\begin{array}{l}\text { Karimi et al, } \\
\text { 2016, Iran [18] }\end{array}$ & 26 & 50 & 58 & - & - & - & Yes \\
\hline $\begin{array}{l}\text { DNA } \\
\text { polymerase }\end{array}$ & Fresh & $\begin{array}{l}\text { Quantitative real } \\
\text { time PCR }\end{array}$ & $\begin{array}{l}\text { Mohammed et al, } \\
\text { 2015, Iraq [19] }\end{array}$ & 9 & 50 & 23.7 & - & - & - & Yes \\
\hline pp65 & Fresh & quantitative PCR & $\begin{array}{l}\text { Richardson et al, } \\
\text { 2015, New Zealand [20] }\end{array}$ & 0 & 70 & 0 & 2 & 70 & 3 & No \\
\hline UL55 & Blood & PCR & $\begin{array}{l}\text { Al.Baiati et al, } \\
\text { 2014, Iraq [21] }\end{array}$ & 26 & 30 & 87 & 41 & 50 & 82 & Yes \\
\hline UL97 & & & & 20 & 30 & 67 & 33 & 50 & 66 & \\
\hline $\mathrm{gB}$ & Fresh & PCR & $\begin{array}{l}\text { Ahani et al, } \\
\text { 2013, Iran [22] }\end{array}$ & 15 & 23 & 65.2 & - & - & - & Yes \\
\hline \multirow[t]{3}{*}{$\begin{array}{l}\text { UL122 and } \\
\text { UL83 }\end{array}$} & paraffin & Real-time PCR & $\begin{array}{l}\text { Barillas et al, } \\
\text { 2013, Mexican [23] }\end{array}$ & 2 & 27 & 7.4 & 0 & 20 & 0 & No \\
\hline & Fresh & Real-time PCR & $\begin{array}{l}\text { Antonsson et al, } \\
\text { 2012, Australia [24] }\end{array}$ & 0 & 54 & 0 & - & - & - & No \\
\hline & Paraffin & PCR & $\begin{array}{l}\text { Eghbali et al, } \\
\text { 2012, Iran [25] }\end{array}$ & 2 & 24 & 8.3 & 0 & 24 & 0 & No \\
\hline $\mathrm{gB}$ & FFPE & Nested-PCR & $\begin{array}{l}\text { Harkins et al, 2010, } \\
\text { Birmingham [26] }\end{array}$ & 4 & 8 & 50 & 1 & 4 & 25 & Yes \\
\hline IE2 & Fresh & PCR & $\begin{array}{l}\text { Tsai et al, 2005, } \\
\text { Taiwan [27] }\end{array}$ & 47 & 62 & 76 & 8 & 12 & 67 & Yes \\
\hline
\end{tabular}

reporting countries, number of breast cancer cases, and cases of breast cancer and normal samples that were positive for the CMV.

\section{Detection of CMV Infection by PCR}

Out of 16 studies, 7 studies used PCR method, 7 studies used Real-time method and 2 study used Nested PCR method. Different samples including fresh tissue, FFPE, and blood were evaluated by PCR methods for the presence of virus genome. In all studies that observed the presence of CMV genome in the samples, the prevalence of CMV genome in cancer samples was higher than normal samples. Virus detection was reported from 0 to $87 \%$ in cancer samples and from 0 to $82 \%$ in normal samples. The highest rate of virus detection in cancer samples was reported in the study of Al.Baiati et al, In Iraq and the lowest prevalence of the virus was reported in Sudan, Australia, Iran and New Zealand. Most of the studies related to PCR method are related to Iran, so that out of 16 studies, six studies have been done in Iran.

\section{Serology of CMV Infection for Breast Cancer}

Out of a total of studies, serological methods have been used in 8 studies. Of all serology studies, 8 studies examined anti-CMV IgG, 5 studies examined anti-CMV IgM, and 5 studies examined both antibodies. The level of anti-CMV IgG was higher than anti-CMV IgM in all studies and also the level of antibodies was higher in cancer samples than normal samples. The prevalence range of anti-CMV IgG was 70 to $100 \%$ and anti-CMV IgM was 0 to $76.7 \%$ in cancer samples and 90 to $100 \%$ for anti-CMV IgG and 0 to $57 \%$ for anti-CMV IgM in normal samples. The highest prevalence of anti-CMV $\mathrm{IgG}$ was from Iraq, Egypt and India and for anti-CMV IgM were from Iraq and Australia. The lowest level of anti-CMV IgG was observed in studies related to New Zealand and India and for anti-CMV IgM was observed in studies related to Egypt and India.

\section{Detection of CMV Infection by IHC and ISH}

The use of methods other than PCR, Real-time PCR, 


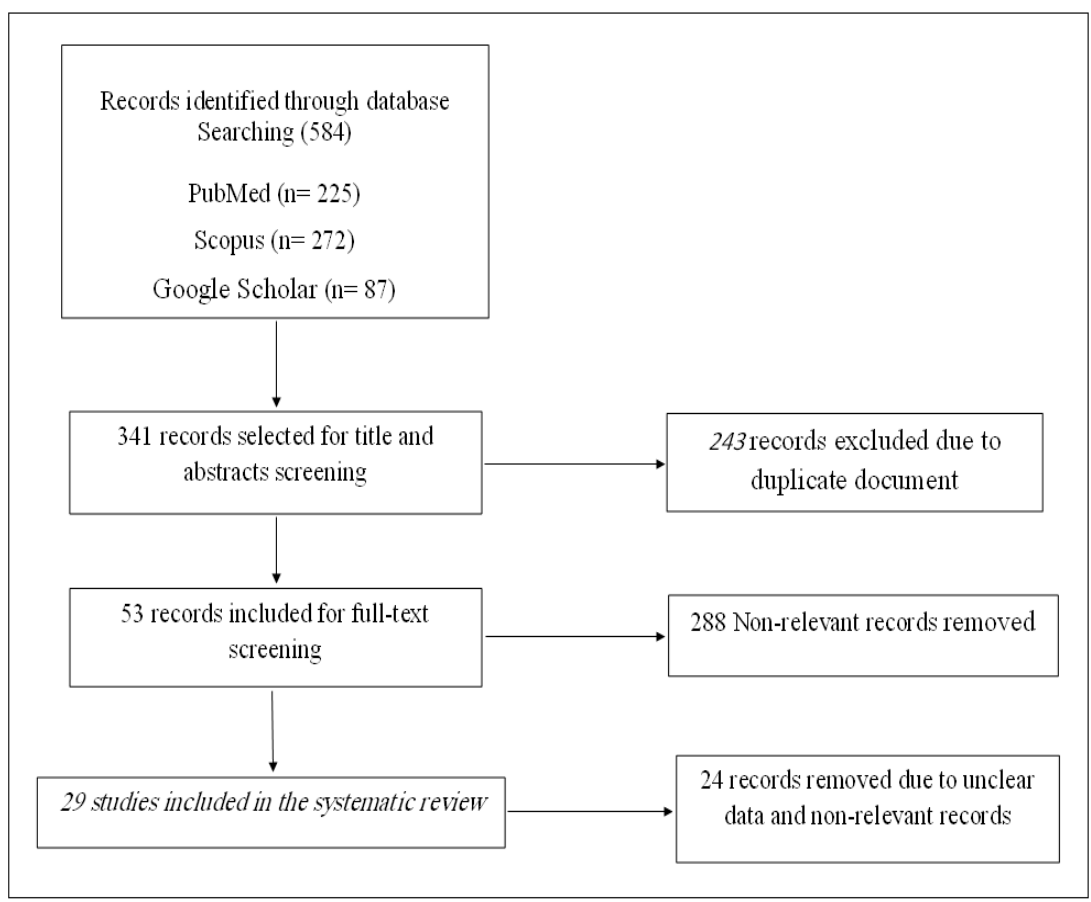

Figure 1. Flowchart of Systematic Literature Search and Article Selection

and ELISA that included IHC and ISH accounted for 13 of the total studies. There were fewer studies using ISH method than the other methods, so that among the total studies, in 4 studies ISH method and 9 studies IHC method was used. The results of using these methods showed a higher prevalence of virus in cancer samples than normal samples. Detection of virus antigens employing IHC in cancer and normal samples was reported to be 0 to $100 \%$, while the rate of ISH was 40 to $100 \%$ and 0 to $67 \%$, respectively. The highest prevalence of the virus was reported in Norway using IHC and ISH. These two techniques are widely used in different studies, especially from conducted investigation in Iraq.

\section{Discussion}

In this systematic review, we tried for the first time to examine the prevalence of HCMV in breast cancer. Among the 29 studies that were finally reviewed, the prevalence of CMV in breast cancer samples in studies that used PCR methods was between 0 and $87 \%$ (Table 1 ). In serological studies the seroprevalence of anti-CMV IgG and $\operatorname{IgM}$ was between $70-100 \%$ and $0-76.7 \%$ respectively (Table 2), and in other studies that served methods like IHC and ISH, the prevalence of the CMV was reported to be $0-100 \%$ and $40-100 \%$, respectively (Table 3 ). In all studies that examined the prevalence of CMV in both cancer and healthy groups, the results indicated that the virus had higher frequency in tumor versus normal samples (Table 1-3).

Due to the advantages of PCR-based methods including conventional PCR. Real-time PCR, and Nested-PCR, they were the most widely used methods in these studies, so that 16 studies from a total of studies served these methods
(Table 1). The advantages of these methods include the sensitivity and rapidity of virus antigens detection than other methods, applicable for archived samples, the ability to detection virus antigens and its genome in various samples such as whole blood, leukocytes, plasma, body fluids (urine, CSF, BAL) or any other tissue (tissue biopsy samples) [41-42]. Although the Real-time PCR is more expensive than the antigen detection methods, it is faster and more automated and provides continuous monitoring of patients who are at risk of CMV for prophylactic treatment and determination of response to treatment [43]. Lack of distinction between active and inactive infections is one of the most important limitations of PCR-based methods [44], which causes other methods such as serology to be used in some of studies, as almost one third of the studies in this research have used serological methods such as ELISA (Table 2). Advantages of ELISA comprising of simplicity, cheapness and ability of determining the history of infection (early or late) make this method suitable for evaluating the presence of virus [42]. However, the less sensitivity and higher false results convinced some researchers to use other methods such as IHC or ISH to assess the presence of the virus [45]. Of the 29 studies reviewed, 13 studies used IHC or ISH techniques (Table 3). Since techniques such as IHC is the gold standard for the identification of CMV antigens presence in fresh tissue and FFPE, some of our studies served these techniques to accurately investigate the presence of viral antigens in malignant epithelial cells or non-epithelial cells [46].

Investigations have shown that all viral antigens are not required for tumorigenesis. CMV immediately early antigen (IE Ag) is known to be necessary for regulating the expression of other viral genes, replication, and cell transformation, therefore, in most studies, IE Ag has been 
Table 2. Comparison of CMV Positivity between Breast Tumor Tissue and any Controls by Serologic Methods

\begin{tabular}{|c|c|c|c|c|c|c|c|c|c|}
\hline \multirow[t]{2}{*}{ Ig } & \multirow[t]{2}{*}{ Test } & \multirow[t]{2}{*}{ Studies } & \multicolumn{3}{|c|}{ Cases } & \multicolumn{3}{|c|}{ Controls } & \multirow{2}{*}{$\begin{array}{l}\text { Significant } \\
\text { Correlation }\end{array}$} \\
\hline & & & $\begin{array}{c}\text { No. } \\
\text { Positive }\end{array}$ & $\begin{array}{c}\text { No. } \\
\text { Tested }\end{array}$ & Positivity & $\begin{array}{c}\text { No. } \\
\text { Positive }\end{array}$ & $\begin{array}{c}\text { No. } \\
\text { Tested }\end{array}$ & Positivity & \\
\hline $\operatorname{IgG}$ & ELISA & $\begin{array}{l}\text { Salman et al, } \\
\text { 2020, Iraq. [28] }\end{array}$ & 67 & 71 & 94.3 & 19 & 20 & 95 & Yes \\
\hline $\operatorname{IgG}$ & $\begin{array}{c}\text { Indirect } \\
\text { chemi-luminescent } \\
\text { immunoassay }\end{array}$ & $\begin{array}{l}\text { Surendran et al, } \\
\text { 2019, India. [29] }\end{array}$ & 88 & 88 & 100 & 42 & 42 & 100 & No \\
\hline $\operatorname{IgM}$ & & & 0 & 88 & 0 & 0 & 42 & 0 & \\
\hline IgG & ELISA & $\begin{array}{l}\text { Al Nuimi et al, } \\
\text { 2018, Iraq. [30] }\end{array}$ & 60 & 60 & 100 & 9 & 10 & 90 & Yes \\
\hline $\operatorname{IgM}$ & & & 5 & 60 & 8.3 & 0 & 10 & 0 & \\
\hline $\operatorname{IgG}$ & ELISA & $\begin{array}{l}\text { El Shazly et al, } \\
\text { 2018, Egypt. [13] }\end{array}$ & 40 & 40 & 100 & 41 & 41 & 100 & Yes \\
\hline $\operatorname{IgM}$ & & & 0 & 40 & 0 & 0 & 41 & 0 & \\
\hline $\operatorname{IgG}$ & ELISA & $\begin{array}{l}\text { Mohammed et al, } \\
\text { 2015, Iraq. [31] }\end{array}$ & 30 & 30 & 100 & 30 & 30 & 100 & Yes \\
\hline $\operatorname{IgM}$ & & & 23 & 30 & 76.7 & 15 & 30 & 50 & \\
\hline $\operatorname{IgG}$ & $\begin{array}{l}\text { Standard enzyme } \\
\text { immunoassays }\end{array}$ & $\begin{array}{l}\text { Richardson et al, } \\
\text { 2015, New Zealand. [20] }\end{array}$ & 49 & 70 & 70 & - & - & - & Yes \\
\hline $\operatorname{IgG}$ & ELISA & $\begin{array}{l}\text { Al-Saady et al, } \\
\text { 2014, Iraq. [32] }\end{array}$ & 30 & 30 & 100 & 91 & 98 & 93 & Yes \\
\hline $\operatorname{IgM}$ & & & 18 & 30 & 60 & 12 & 98 & 12 & \\
\hline $\operatorname{IgG}$ & $\begin{array}{c}\text { Enzyme } \\
\text { immunoassays }\end{array}$ & $\begin{array}{l}\text { Richardson et al, } \\
\text { 2004, Australia. [33] }\end{array}$ & 122 & 208 & 59 & 97 & 169 & 57 & Yes \\
\hline
\end{tabular}

evaluated as a target antigen by IHC [47-48]. In addition, this Ag, along with glycoprotein B or UL55, were the most widely used genes in evaluation of CMV genome presence by PCR methods (Table 1,3). Glycoprotein B is considered as a virus ligand and essential for infectivity of virus [49]. Glycoprotein B nucleotide sequence is highly conserved, explaining its utilization as a detection target in various studies [49]. Although these studies have evaluated the virus in a variety of tissues, including fresh, FFPE, and blood, the major part of virus detection using this gene was reported in blood and fresh tissue [21-22].

In serological studies, among the all anti-CMV antibodies, the $\operatorname{IgG}$ and IgM were evaluated as a major indicator for viral presence (Table 2). The prevalence of anti-CMV IgG was examined in all serological studies, but the prevalence of anti-CMV IgM was examined only in three-quarters of studies along with anti-CMV IgG (Table 2). The results of studies showed a very high prevalence of anti-CMV IgG in both cancer and normal groups compared to the serum prevalence of anti-CMV IgM (Table 2). Due to the higher prevalence of anti-CMV IgG and especially anti-CMV IgM in the cancer group than the normal group (Table 2), serological studies suggest the probable role of the CMV in the development of breast cancer (Table 2). Since anti-CMV IgM can be present in both recent infection and viral reactivation which shows non-specificity for primary infection, the possibility of false positive results, and its inefficiency in the cases of immunocompromised patients, is not proposed as a highly useful indicator of virus infection [42]. On the other hand, anti-CMV IgG, which indicate previous exposure with the virus, can considered as a good indicator for last presence of HCMV infection [42].

Among serological studies, the highest prevalence of anti-CMV IgG has been reported in Asian countries such as Iraq, India, and African countries such as Egypt, as well as the highest prevalence of anti-CMV IgM was related to Iraq (Table 2). The highest viral detection rate based on PCR techniques was related to Asian countries such as Iraq, Iran (Zabul) and Taiwan (Table 1). The highest prevalence of the virus detection in tissue samples by means of IHC and hybridization methods was reported from Asian countries such as Iraq and China and European countries including Norway and the Birmingham, as well (Table 3). In general, the results obtained from different methods illustrate the high prevalence of CMV in Asian and African countries and its relatively lower prevalence in European and South American countries (Table 1-3). Since the prevalence of this virus directly depends on environmental factors such as social and economic conditions and even the cultural traditions, many studies have reported that low income and social status in third world countries is related to the higher prevalence of CMV [50-52]. For example, in areas such as Iraq, where families have a population of more than three, the prevalence of anti-CMV IgG and IgM determined to have an increasing trend [50].

The comparative analysis demonstrates the studies which employed serological and IHC methods identified higher presence of infection than PCR methods (Table 1-3). In this line it should be mentioned that sometimes even in CMV-positive tumor samples, many tumor cells do 
Table 3. Comparison of CMV Positivity between Breast Tumor Tissue and any Controls by IHC and ISH

\begin{tabular}{|c|c|c|c|c|c|c|c|c|c|}
\hline \multirow[t]{2}{*}{$\mathrm{Ag}$} & \multirow[t]{2}{*}{ Test } & \multirow[t]{2}{*}{ Studies } & \multicolumn{3}{|c|}{ Cases } & \multicolumn{3}{|c|}{ Controls } & \multirow{2}{*}{$\begin{array}{l}\text { Significant } \\
\text { Correlation }\end{array}$} \\
\hline & & & $\begin{array}{c}\text { No. } \\
\text { Positive }\end{array}$ & $\begin{array}{c}\text { No. } \\
\text { Tested }\end{array}$ & Positivity & $\begin{array}{c}\text { No. } \\
\text { Positive }\end{array}$ & $\begin{array}{l}\text { No. } \\
\text { Tested }\end{array}$ & Positivity & \\
\hline IE & Immunohistochemistry & $\begin{array}{l}\text { Costa et al, } \\
\text { 2019, Norway. [34] }\end{array}$ & 55 & 75 & 73 & 2 & 26 & 8 & Yes \\
\hline $\begin{array}{l}\text { Early } \\
\text { Ag }\end{array}$ & Immunohistochemistry & $\begin{array}{l}\text { Al Nuimi et al, } \\
\text { 2018, Iraq. [35] }\end{array}$ & 56 & 60 & 93 & 2 & 10 & 20 & Yes \\
\hline Late Ag & & & 37 & 60 & 61.7 & 7 & 10 & 70 & \\
\hline IE & Immunohistochemistry & $\begin{array}{l}\text { Cui et al, } \\
\text { 2018, china. [36] }\end{array}$ & 62 & 68 & 92.6 & 70 & 146 & 47.9 & Yes \\
\hline LA & & & 62 & 68 & 92.6 & 78 & 146 & 53.4 & \\
\hline E/IE & Immunohistochemistry & $\begin{array}{l}\text { El Shazly et al, } \\
\text { 2018, Egypt. [13] }\end{array}$ & 21 & 61 & 34 & 0 & 61 & 0 & Yes \\
\hline PP65 & & & 49 & 61 & 80 & 15 & 61 & 25 & \\
\hline IE & immunohistochemistry & $\begin{array}{l}\text { Mohammadizadeh et al, } \\
\text { 2017, Iran. [16] }\end{array}$ & 0 & 70 & 0 & 0 & 26 & 0 & No \\
\hline IE & Immunohistochemistry & $\begin{array}{l}\text { Rahbar et al, } \\
\text { 2017, Norway. [37] }\end{array}$ & 62 & 62 & 100 & 42 & 42 & 100 & Yes \\
\hline $\mathrm{L}$ & & & 46 & 62 & 75 & 28 & 42 & 68 & \\
\hline Late Ag & Immunohistochemistry & $\begin{array}{l}\text { Ahmed et al, } \\
\text { 2016, Egypt. [38] }\end{array}$ & 47 & 107 & 43.9 & - & - & - & Yes \\
\hline IE1 & Immunohistochemistry & $\begin{array}{l}\text { Mohammed et al, } \\
\text { 2015, Iraq. [31] }\end{array}$ & 34 & 38 & 89.5 & 3 & 30 & 10 & Yes \\
\hline $\mathrm{L}$ & & & 35 & 38 & 92.1 & 0 & 30 & 0 & \\
\hline \multirow[t]{4}{*}{ IE $1 / 2$} & immunohistochemistry & $\begin{array}{l}\text { Harkins et al, } \\
\text { 2010, Birmingham. [26] }\end{array}$ & 38 & 39 & 97 & 24 & 38 & 63 & Yes \\
\hline & $\begin{array}{l}\text { Ultra- sensitive version of } \\
\text { chromogenic in situ hybridization }\end{array}$ & $\begin{array}{l}\text { Alajeely et al, } \\
\text { 2019, Iraq. [39] }\end{array}$ & 8 & 20 & 40 & 0 & 20 & 0 & Yes \\
\hline & $\begin{array}{l}\text { Ultra- sensitive version of } \\
\text { chromogenic in situ hybridization }\end{array}$ & $\begin{array}{l}\text { Ali et al, } \\
\text { 2018, Iraq. [40] }\end{array}$ & 17 & 30 & 56.7 & 0 & 15 & 0 & Yes \\
\hline & In situ hybridization & $\begin{array}{l}\text { Rahbar et al, } \\
\text { 2017, Norway. [37] }\end{array}$ & 23 & 23 & 100 & - & - & - & Yes \\
\hline IE1 & In situ hybridization & $\begin{array}{l}\text { Harkins et al, } \\
\text { 2010, Birmingham. [26] }\end{array}$ & 16 & 18 & 89 & 11 & 18 & 61 & Yes \\
\hline
\end{tabular}

not contain the virus genome. This may be explained by specific event during the carcinogenesis. The findings suggest the role of two mechanisms of hit-run and oncomodulation. Oncomodulation defines as the mechanism of enhancing cellular malignancy following CMV infection [53]. This mechanism is carried out through specific CMV proteins including IE, US28, pp65, and ul44 which disrupts signaling pathways, transcription factors and tumor suppressor proteins in the epithelium of tumors and participates in increasing mutations, angiogenesis and facilitates the immune system evasion for tumor progression [11]. The 'hit and run' hypothesis is suggested as a main mechanism involved in viral transformation. In "hit-and-run" hypothesis, the virus can exert its long-term effect on cellular process to drive transformation when viral genomes are not present, supporting the importance of last exposure with viral infections [54].

In the case of anti-CMV therapies, as a result of virus ability in establishing latency in infected cells, no definitive treatment has been proposed for the infection [10]. However, the findings of previous studies in CMVassociated gliomablastoma provided promising results that have been achieved by targeting CMV in these patients using the therapies including the drug of valganciclovir, DC vaccine, and anti-HCMV targeted T cell therapy [10]. Some investigations introduce the utilization of a combination of therapies that induce the expression of viral lytic phase genes and expose the virus-containing tumor cells, is the best treatment strategy for herpesviruses in their latency form [10].

In conclusion, collectively, the majority of studies highlighted the possible role of CMV in developing breast carcinoma. Reviewing of all data showed the prevalence rate of CMV in patients with breast cancer is higher in low-income and third world countries than developed countries, proposing CMV prevalence may be affected by socio-economic status and environmental factors. The survey of methodology represents each technique has different sensitivity, specificity, and reliability in comparison with others. The characteristic of CMV in establishing latent form of infection is a significant ongoing limitation for anti-CMV therapies and the future investigation should focus on finding a promising solution for this issue. 


\section{Acknowledgments}

We are thankful to Akram Valizadeh for support the current study.

Conflict of Interests

All authors declared that they have no conflict of interest.

Funding/Support

No.

\section{Financial Disclosures}

The authors have no financial interest related to the material in the manuscript.

\section{References}

1. Bray F, Ferlay J, Soerjomataram I, Siegel RL, Torre LA, Jemal A. Global cancer statistics 2018: GLOBOCAN estimates of incidence and mortality worldwide for 36 cancers in 185 countries. CA: A Cancer Journal for Clinicians. 2018 09 12;68(6):394-424. https://doi.org/10.3322/caac.21492

2. Salamat F, Niakan B, Keshtkar A, Rafiei E, Zendehdel M. Subtypes of benign breast disease as a risk factor of breast cancer: A systematic review and meta analyses. Iranian journal of medical sciences. 2018;43(4):355.

3. Parkin DM, Fernandez LMG. Use of Statistics to Assess the Global Burden of Breast Cancer. The Breast Journal. 2006 01;12(s1):S70-S80. https://doi.org/10.1111/j.1075122x.2006.00205.x

4. DeSantis C, Ma J, Bryan L, Jemal A. Breast cancer statistics, 2013. CA: A Cancer Journal for Clinicians. 2013 Oct 01;64(1):52-62. https://doi.org/10.3322/caac.21203

5. Ferlay J, Soerjomataram I, Ervik M, Dikshit R, Eser S, Mathers $\mathrm{C}$, et al. Cancer incidence and mortality worldwide: IARC CancerBase. Globocan. 2012;2013(1):11.

6. Parkin DM. The global health burden of infection-associated cancers in the year 2002. International Journal of Cancer. 2006;118(12):3030-3044. https://doi.org/10.1002/ijc.21731

7. Gannon O, Antonsson A, Bennett I, Saunders N. Viral infections and breast cancer - A current perspective. Cancer Letters. 2018 04;420:182-189. https://doi.org/10.1016/j. canlet.2018.01.076

8. Geisler J, Touma J, Rahbar A, Söderberg-Nauclér C, Vetvik K. A Review of the Potential Role of Human Cytomegalovirus (HCMV) Infections in Breast Cancer Carcinogenesis and Abnormal Immunity. Cancers. 2019 Nov 22;11(12):1842. https://doi.org/10.3390/cancers11121842

9. Michaelis M, Doerr HW, Cinatl J. The Story of Human Cytomegalovirus and Cancer: Increasing Evidence and Open Questions. Neoplasia. 2009 01;11(1):1-9. https://doi. org/10.1593/neo.81178

10. Nauclér CS, Geisler J, Vetvik K. The emerging role of human cytomegalovirus infection in human carcinogenesis: a review of current evidence and potential therapeutic implications. Oncotarget. 201907 02;10(42):4333-4347. https://doi. org/10.18632/oncotarget.27016

11. Nakhaie M, Charostad J, Kaydani GA, Faghihloo E. The role of viruses in adenocarcinoma development. Infection, Genetics and Evolution. 2020 Dec;86:104603. https://doi. org/10.1016/j.meegid.2020.104603

12. Aidrous R, El Hussein A, Dahawi S, Elkhidir I, Enan K. Molecular Detection of Epstein-Barr Virus and Human Cytomegalovirus Antigen Expression in Breast Cancer in
Khartoum State, Sudan 2018.2019.

13. Sepahvand P, Makvandi M, Samarbafzadeh A, Talaei-Zadeh A, Ranjbari N, Nisi N, Azaran A, Jalilian S, Pirmoradi R, Makvandi K, Ahmadi Angali K. Human Cytomegalovirus DNA among Women with Breast Cancer. Asian Pacific Journal of Cancer Prevention. 2019 08 01;20(8):2275-2279. https://doi.org/10.31557/apjcp.2019.20.8.2275

14. El Shazly DF, Bahnassey AA, Omar OS, Elsayed ET, Al-Hindawi A, El-Desouky E, Youssef H, Zekri AN. Detection of Human Cytomegalovirus in Malignant and Benign Breast Tumors in Egyptian Women. Clinical Breast Cancer. 2018 08;18(4):e629-e642. https://doi.org/10.1016/j. clbc.2017.10.018

15. A. L. Shadood HK, Atiya SA, Kardar GA. Correlation of Breast Cancer with the Epstein Bar Virus and Human Cytomegalovirus Frequency and the Expression of Estrogen Receptor-Beta and IL-6 Receptor in Iraqi Women. Natural Science. 2018;10(05):182-192. https://doi.org/10.4236/ ns.2018.105020

16. Bakhtiarizadeh S, Hosseini SY, Yaghobi R, Safaei A, Sarvari J. Almost Complete Lack of Human Cytomegalovirus and Human papillomaviruses Genome in Benign and Malignant Breast Lesions in Shiraz, Southwest of Iran. Asian Pacific Journal of Cancer Prevention. 2017 Dec;18(12). https://doi. org/10.22034/APJCP.2017.18.12.3319

17. Mohammadizadeh F, Mahmudi F. Evaluation of human cytomegalovirus antigen expression in invasive breast carcinoma in a population of Iranian patients. Infectious Agents and Cancer. 201706 26;12(1). https://doi. org/10.1186/s13027-017-0148-3

18. Karimi M, Hosseini* SZ, Nikkhoo B, Mohammadi FS. Relative Frequency of Cytomegalovirus (CMV) in Tissue Samples of Women with Breast Cancer in Sanandaj, Iran.. International Journal of Bioassays. 201603 01;5(03):4907. https://doi.org/10.21746/ijbio.2016.03.0014

19. Mohammed A, Kadhim H, Hussein A. Investigation the role of human cytomegalovirus in the invasive ductal breast carcinoma using real time PCR. Int J Curr Microbiol App Sci. 2015;4(1):537-42.

20. Richardson AK, Currie MJ, Robinson BA, Morrin H, Phung Y, Pearson JF, Anderson TP, Potter JD, Walker LC. Cytomegalovirus and Epstein-Barr Virus in Breast Cancer. Adamson A. PLOS ONE. 201502 27;10(2):e0118989. https://doi.org/10.1371/journal.pone.0118989

21. Hussein AMAB, Rebah N, Jabbar2, Mohammed A, AlSaady3, A.Muhsin3 aM. Molecular Detection of Human Cytomegalovirus genes in infertile and breast cancer women in Baghdad province. Int J Curr Microbiol App Sci. 2014;3(4):316-22.

22. Ahani N, Alipour M, Nikravesh A. Detection of Human Cytomegalovirus in Breast Cancer by Polymerase Chain Reaction (PCR). Shahid Beheshti University Of Medical Of Sciences. 2013;8.

23. Utrera-Barillas D, Valdez-Salazar H, Gómez-Rangel D, Alvarado-Cabrero I, Aguilera P, Gómez-Delgado A, RuizTachiquin M. Is human cytomegalovirus associated with breast cancer progression?. Infectious Agents and Cancer. 2013;8(1):12. https://doi.org/10.1186/1750-9378-8-12

24. Antonsson A, Bialasiewicz S, Rockett RJ, Jacob K, Bennett IC, Sloots TP. Exploring the Prevalence of Ten Polyomaviruses and Two Herpes Viruses in Breast Cancer. Buck CB. PLoS ONE. 201208 15;7(8):e39842. https://doi. org/10.1371/journal.pone.0039842

25. Eghbali M, Ghane M, Mirinargesi M. Frequency of cytomegalovirus (CMV) in benign and malignant tumors. International Journal of Molecular and Clinical Microbiology. 2012;2(2):175-9. 
26. Harkins LE, Matlaf LA, Soroceanu L, Klemm K, Britt WJ, Wang W, Bland KI, Cobbs CS. Detection of human cytomegalovirus in normal and neoplastic breast epithelium. Herpesviridae. 2010;1(1):8. https://doi.org/10.1186/20424280-1-8

27. Tsai J, Tsai C, Cheng M, Lin S, Xu F, Yang C. Association of viral factors with non-familial breast cancer in Taiwan by comparison with non-cancerous, fibroadenoma, and thyroid tumor tissues. Journal of Medical Virology. 2004;75(2):276281. https://doi.org/10.1002/jmv.20267

28. Salman O, Al-Azzawi R. Seroprevalence of human cytomegalovirus in iraqi breast cancer patients. Plant Archives. 2020;20:729-31.

29. Surendran A, Chisthi MM. Breast Cancer Association with Cytomegalo Virus-A Tertiary Center Case-Control Study. Journal of Investigative Surgery. 2017 Dec 18;32(2):172177. https://doi.org/10.1080/08941939.2017.1397827

30. AlNuaimi B, Al-Azzawi R, Naji R. Serodiagnosis of Human Cytomegalovirus in Iraqi Breast cancer and fibroadenoma patients. Current Research in Microbiology and Biotechnology. 2018;6(1):1466-9.

31. Mohammed A, Kadhim H, Ghani A. Investigation the role of human cytomegalovirus in the invasive ductal breast carcinoma. Clinical Cancer Investigation Journal. 2015;4(2):199. https://doi.org/10.4103/2278-0513.148915

32. Al-Saady M. Serodiagnosis of Human Cytomegalovirus in infertile and breast cancer women in Baghdad province. Int J Curr Microbiol App Sci. 2014;3(4):290-5.

33. Richardson AK, Cox B, McCredie MRE, Dite GS, Chang J, Gertig DM, Southey MC, Giles GG, Hopper JL. Cytomegalovirus, Epstein-Barr virus and risk of breast cancer before age 40 years: a case-control study. British Journal of Cancer. 200404 20;90(11):2149-2152. https:// doi.org/10.1038/sj.bjc.6601822

34. Costa H, Touma J, Davoudi B, Benard M, Sauer T, Geisler J, Vetvik K, Rahbar A, Söderberg-Naucler C. Human cytomegalovirus infection is correlated with enhanced cyclooxygenase- 2 and 5-lipoxygenase protein expression in breast cancer. Journal of Cancer Research and Clinical Oncology. 201906 15;145(8):2083-2095. https://doi. org/10.1007/s00432-019-02946-8

35. Al-Nuaimi BN, Al-Azzawi RH, Naji RZ. Association of human cytomegalovirus with HER2 proto-oncogene overexpression in iraqi breast cancer patients. Biochem. Cell. Arch. 2019;19(1):1691-1698

36. Cui J, Wang Q, Wang H, Wang B, Li L. Protein and DNA evidences of HCMV infection in primary breast cancer tissues and metastatic sentinel lymph nodes. Cancer Biomarkers. 201803 14;21(4):769-780. https://doi. org/10.3233/CBM-170409

37. Rahbar A, Touma J, Costa H, Davoudi B, Bukholm IR, Sauer T, Vetvik K, Geisler J, Söderberg-Naucler C. Low Expression of Estrogen Receptor- $\alpha$ and Progesterone Receptor in Human Breast Cancer Tissues Is Associated With High-Grade Human Cytomegalovirus Protein Expression. Clinical Breast Cancer. 2017 Nov;17(7):526-535.e1. https:// doi.org/10.1016/j.clbc.2017.04.013

38. Ahmed RA, Yussif SM. Immunohistochemical detection of human cytomegalovirus, Epstein-Barr virus and human papillomavirus in invasive breast carcinoma in Egyptian women: A tissue microarray study. Journal of Solid Tumors. 201603 30;6(2). https://doi.org/10.5430/jst.v6n2p8

39. Alajeely A, Mahmood A, Zangor J, Ali SHM. Assessment of breast cancer tissue microenvironment for human cytomegalovirus infection and CD4- and CD8- positive tumor infiltrating lymphocytes. Biochem Cell Arch.
2019;19:2499-505.

40. Ali S, Almahbobi T, Al-Bayaa Y, Al-Alwany S. Impact of human cytomegalovirus infection associated with the expressed protein of mutated BRCA1 gene in breast tissues from a group of Iraqi female patients with breast carcinoma. Research Journal of Pharmacy and Technology. 2018;11(4):1505-12.

41. Garibyan L, Avashia N. Polymerase Chain Reaction. Journal of Investigative Dermatology. 2013 03;133(3):1-4. https:// doi.org/10.1038/jid.2013.1

42. A. Ross S, Novak Z, Pati S, B. Boppana S. Overview of the Diagnosis of Cytomegalovirus Infection. Infectious Disorders - Drug Targets. 2011 Oct 01;11(5):466-474. https:// doi.org/10.2174/187152611797636703

43. Azevedo L, Pierrotti L, Abdala E, Costa S, Strabelli T, Campos S, Ramos J, Latif A, Litvinov N, Maluf N, Caiaffa Filho H, Pannuti C, Lopes M, Santos V, Linardi C, Yasuda $\mathrm{M}$, Marques H. Cytomegalovirus infection in transplant recipients. Clinics. 201507 12;70(7):515-523. https://doi. org/10.6061/clinics/2015(07)09

44. Rodríguez RA, Pepper IL, Gerba CP. Application of PCRBased Methods To Assess the Infectivity of Enteric Viruses in Environmental Samples. Applied and Environmental Microbiology. 2008 Nov 14;75(2):297-307. https://doi. org/10.1128/aem.01150-08

45. Al-Taie A, Abdullah B, Al-Attar M. Serological and Molecular Comparison Study for Diagnosis of Cytomegalovirus Infection in aborted Pregnant Women in Iraq. Rafidain Journal of Science. 2018 Dec 01;27(4):81-89. https://doi. org/10.33899/rjs.2018.159336

46. Mills AM, Guo FP, Copland AP, Pai RK, Pinsky BA. A Comparison of CMV Detection in Gastrointestinal Mucosal Biopsies Using Immunohistochemistry and PCR Performed on Formalin-fixed, Paraffin-embedded Tissue. American Journal of Surgical Pathology. 2013 07;37(7):995-1000. https://doi.org/10.1097/pas.0b013e31827fcc33

47. Torres L, Tang Q. Immediate-Early (IE) gene regulation of cytomegalovirus: IE1- and pp71-mediated viral strategies against cellular defenses. Virologica Sinica. 2014 Nov 25;29(6):343-352. https://doi.org/10.1007/s12250-0143532-9

48. Stinski M, Meier J. Immediate-early viral gene regulation and function. Human Herpesviruses: Biology, Therapy, and Immunoprophylaxis. 2007.

49. Novak Z, Chowdhury N, Ross SA, Pati SK, Fowler K, Boppana SB. Diagnostic Consequences of Cytomegalovirus Glycoprotein B Polymorphisms. Journal of Clinical Microbiology. 201106 08;49(8):3033-3035. https://doi. org $/ 10.1128 / \mathrm{jcm} .01039-11$

50. Aljumaili ZKM, Alsamarai AM, Najem WS. Cytomegalovirus seroprevalence in women with bad obstetric history in Kirkuk, Iraq. Journal of Infection and Public Health. 2014 07;7(4):277-288. https://doi.org/10.1016/j.jiph.2013.08.006

51. DOWD JB, AIELLO AE, ALLEY DE. Socioeconomic disparities in the seroprevalence of cytomegalovirus infection in the US population: NHANES III. Epidemiology and Infection. 200804 16;137(1):58-65. https://doi. org/10.1017/s0950268808000551

52. Basha J, Iwasenko JM, Robertson P, Craig ME, Rawlinson WD. Congenital cytomegalovirus infection is associated with high maternal socio-economic status and corresponding low maternal cytomegalovirus seropositivity. Journal of Paediatrics and Child Health. 201403 05;50(5):368-372. https://doi.org/10.1111/jpc.12502

53. Michaelis M, Doerr HW, Cinatl J. Oncomodulation by human cytomegalovirus: evidence becomes stronger. Medical 
Microbiology and Immunology. 200902 07;198(2):79-81. https://doi.org/10.1007/s00430-009-0107-8

54. Niller HH, Wolf H, Minarovits J. Viral hit and runoncogenesis: Genetic and epigenetic scenarios. Cancer Letters. 2011 06;305(2):200-217. https://doi.org/10.1016/j. canlet.2010.08.007

\section{$\Theta(\Theta \Theta$}

This work is licensed under a Creative Commons AttributionNon Commercial 4.0 International License. 